\title{
Musical murmurs on transcranial ultrasound in childhood migraine with aura
}

\section{田}

A 12-year-old girl presented with headache, nausea, decreased level of consciousness, and diplopia. Brain MRI, arteriography (figure e-1 on the Neurology ${ }^{\circledR}$ Web site at www.neurology.org), vasculitic markers, and CSF were normal, as were EEGs and ECGs. Transcranial color-coded ultrasonography of the basilar artery revealed typical musical murmurs ("seagull cry") indicative of a hemodynamically significant stenosis (video). ${ }^{1}$ Sumatriptan provided symptomatic relief; basilar flow normalized on ultrasonography (figure e-2). The clinical presentation suggested childhood migraine with aura; the ultrasound and normal arteriography suggested focal, transient vasospasm during a migraine attack. Topiramate was effective long-term. The high prevalence of childhood migraine (up to $>20 \%)^{2}$ suggests that ultrasound may be a useful diagnostic tool.

Peter Kraft, $M D$, Wolfgang Müllges, $M D$

From the Department of Neurology, University Hospital of Würzburg, Germany.

Author contributions: Peter Kraft: drafting/revising the manuscript, study concept or design, analysis or interpretation of data, accepts responsibility for conduct of research and final approval. Wolfgang Müllges: drafting/revising the manuscript, analysis or interpretation of data, accepts responsibility for conduct of research and final approval, acquisition of data.

Acknowledgment: The authors thank Martin Schuhmann and Bernhard Ludewig for adapting the video file and Mira Schließer for valuable assistance in the ultrasound laboratory.

Study funding: No targeted funding reported.

Supplemental data at www.neurology.org
Disclosure: The authors report no disclosures relevant to the manuscript. Go to Neurology.org for full disclosures.

Correspondence to Dr. Kraft: kraft_p1@klinik.uni-wuerzburg.de

1. Lin SK, Ryu SJ, Chang YJ, Lee TH. Clinical relevance of musical murmurs in color-coded carotid and transcranial duplex sonographies. Am J Neuroradiol 2006;27:1493-1497.

2. Gelfand AA, Fullerton HJ, Goadsby PJ. Child neurology: migraine with aura in children. Neurology 2010;75:e16-e19. 


\section{Neurology}

\section{Musical murmurs on transcranial ultrasound in childhood migraine with aura Peter Kraft and Wolfgang Müllges \\ Neurology 2013;81;1880 \\ DOI 10.1212/01.wnl.0000436064.90018.48}

\section{This information is current as of November 18, 2013}

\section{Updated Information \& Services}

Supplementary Material

\section{References}

Subspecialty Collections

Permissions \& Licensing

\section{Reprints}

including high resolution figures, can be found at: http://n.neurology.org/content/81/21/1880.full

Supplementary material can be found at: http://n.neurology.org/content/suppl/2013/11/17/81.21.1880.DC1 http://n.neurology.org/content/suppl/2013/11/17/81.21.1880.DC2

This article cites 2 articles, 1 of which you can access for free at: http://n.neurology.org/content/81/21/1880.full\#ref-list-1

This article, along with others on similar topics, appears in the following collection(s):

Migraine

http://n.neurology.org/cgi/collection/migraine

Pediatric headache

http://n.neurology.org/cgi/collection/pediatric_headache Ultrasound

http://n.neurology.org/cgi/collection/ultrasound

Information about reproducing this article in parts (figures,tables) or in its entirety can be found online at:

http://www.neurology.org/about/about_the_journal\#permissions

Information about ordering reprints can be found online:

http://n.neurology.org/subscribers/advertise

Neurology ${ }^{\circledR}$ is the official journal of the American Academy of Neurology. Published continuously since 1951, it is now a weekly with 48 issues per year. Copyright @ 2013 American Academy of Neurology. All rights reserved. Print ISSN: 0028-3878. Online ISSN: 1526-632X.

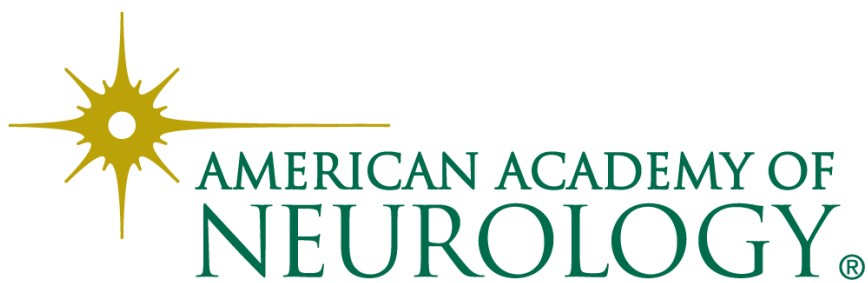

